\title{
The Concept of Charity in Islam: An Analysis on the Verses of the Quran and Hadith
}

\author{
Salwa Amirah Awang \\ University of Malaya, salwa1680@gmail.com \\ Fidlizan Muhammad \\ Universiti Pendidikan Sultan Idris, fidlizan@fpe.upsi.edu.my \\ Joni Tamkin Borhan \\ University of Malaya, joni@um.edu.my \\ Mohammad Taqiuddin Mohamad \\ University of Malaya, m.taqiuddin@um.edu.my
}

\begin{abstract}
Charitable giving is deemed as one of the most important obligations in Islam which impacts in the wellbeing of an individual and the welfare of the society as a whole. Thus, this paper aims to explore the concept of charity in Islam by basing on the two important sources which are the Quran and Hadith. An analysis based on the verses of Quran and Hadith pertaining to charity is conducted and it is found that there are two words commonly used for charity in Islam which are sadaqah and infaq. Further probe on the definition and types of charity yields a result of a complete classification of charity which is broken down into two major categories; the mandatory and the voluntary charitable giving. Four conditions of charity are also discussed which are the donor, recipient, gift and intention describing the flexibility and dynamic of this act. Lastly, some verses of Quran containing the economic role of charitable giving are examined showing the growing nature of this act that promotes prosperity to the donor, recipient and the society.
\end{abstract}

Keywords: charitable giving, șadaqah, society welfare, individual wellbeing

\section{Introduction}

Charitable giving is one of the most fundamental obligations prescribed in Islam. It is highly encouraged and emphasized in the Quran and Hadith as the noblest way of spending the wealth for the sake of Allah and helping the needy which should be the common practice of every Muslim. Charitable giving is not just a means of spiritual purification, but also as a tool for building 
socio-economic sustainability ${ }^{1}$ and social reforms resulting in the wellbeing of an individual and society in the world and hereafter. In general, charity is defined as an organization that raises money to help people in need and also an act of kindness and understanding towards others ${ }^{2}$. It is also described as the benevolent act toward the love of humanity pertaining to generosity and helpfulness toward people in need by giving aid in terms of food, money or others. In Islam, charity comes from an Arabic word șadaqah which according to Ibn Manzūr ${ }^{3}$ has several meanings. Firstly, sadaqah means to be truthful which is the antonym to lies and is associated with someone who has noble characters and manners. It is also defined as whatever given to the needy for the sake of Allah and can also means a dowry given by a husband to his wife. Similarly, sadaqah is defined as to be truthful, true or sincere, to speak the truth, to establish or confirm the truth of what is said, to verify, accountability, to keep faith, truth, veracity, sincerity, soundness, excellence in a variety of different objects and the giving for the sake of Allah ${ }^{4}$. In general, sadaqah means a noble act of giving by a person to others sanctified for the sake of Allah in many forms and ways.

\section{Definition of Charity Based on the Quran}

To further understand the meaning and concept of charity in Islam, verses from the Quran containing the command of charity are assessed:

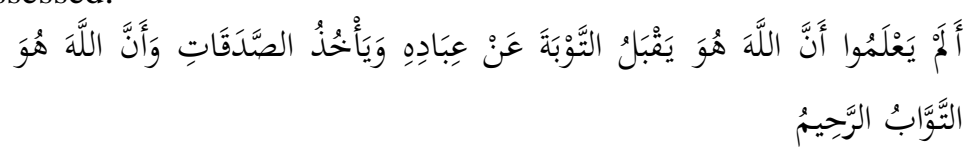

1 Benaouda Bensaid and Fadila Grine, "Ethico-Spiritual Dimensions of Charity: An Islamic Perspective," Middle-East Journal of Scientific Research 13 (2013): 65-77, doi:10.5829/idosi.mejsr.2013.13.e.13015.

2 Federal Chambers, Advanced English Dictionary, English-Bahasa Malaysia Edition (Selangor: Chambers Harrap Publishers ltd, 2000), 187.

3 Muhammad bin Mukarram bin 'Alī Ibn Manz̄ūr, Lisān al- 'Arab (Kaherah: Dār al-Ma'ārif, 1999), 2419.

${ }^{4}$ John Penrice, A Dictionary and Glossary of the Quran (Kuala Lumpur: The Other Press, 2006), 126. 
Translation: "Do they not know that it is Allah who accepts repentance from His servants and receives charities and that it is Allah who is the Accepting of repentance, the Merciful?"5.

Al-Ṭawbah 9:104

According to Ibn Kathīr ${ }^{6}$, this verse contains a command from Allah to perform șadaqah as a way to sanctify and to purify oneself for those who repent for the sins which also includes the meaning of performing zakat. Al-Qurtub $\overline{1}^{7}$ defines the meaning of sadaqah in this verse specifically refers to zakat and discusses the reward given to the donor. Al-Marāghi ${ }^{8}$ expounds the meaning of sadaqah in this verse to whatever spent by the believers for getting closer to Allah which infers to the general charitable giving. These commentaries signal that sadaqah carries the meaning of both the voluntary charitable giving as well as mandatory charitable giving.

Furthermore, sadaqah is also mentioned as a form of penalty in the following verse;

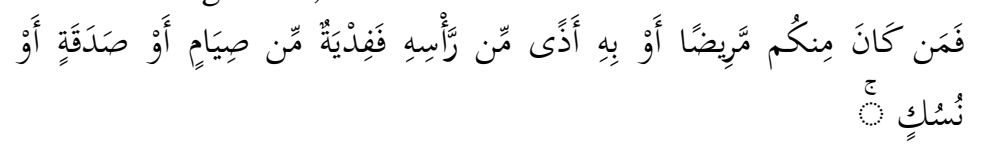

Translation: "And whoever among you is ill or has an ailment of the head [making shaving necessary must offer] a ransom of fasting [three days] or charity or sacrifice"

Al-Baqarah 2:196

The word sadaqah in this verse is interpreted by Ibn Kathīr ${ }^{10}$ based on the hadith narrated by al-Bukhārī as an option of penalty or kaffarah by paying the fidyah in the form of giving food for those who shave their heads due to ailment during Ihram (pilgrimage). The options for the penalty are to pay the fidyah in

\footnotetext{
5 Abdul Malek Mujahid, Tafsir Ibn Katsir/ Abridged by a Group of Scholars under the Supervision of Shaykh Safi Ur Rahman al-Mubarakpuri" (Riyadh: Darussalam Publishers \& Distributors, 2000.

6 Ismā‘̄il bin Kathīr al-Damsyīqīi, Tafsīr al-Qurān al- 'Aż̄im (Egypt: Maktabah al-Tawfiqia, 2000), 143.

7 Muḥammad bin Aḥmad al-Anșārī al-Qurțubī, Al-Jāmi li Ahkām al-Qurān (Cairo: Dār al-Hadīth, 2002), 4:568-569.

8 Aḥmad Mușṭafā al-Marāghī, Tafsir al-Marāghī (Beirut: Dār al- Fikr, 2001), 4:110-112.

9 Abdul Malek Mujahid,Tafsir Ibn Katsir/ Abridged by a Group of Scholars under the Supervision of Shaykh Safi Ur Rahman al-Mubarakpuri, 4: 239.

${ }^{10}$ Ibn Kathīr, Tafsīr al-Qurān al- 'Aẓīm, 1/2, 301.
} 
the form of three days fasting or giving charity by feeding six poor people or sacrificing an animal. Al-Qurtubi ${ }^{11}$ discusess that although it has been agreed unanimously to sacrifice a sheep, scholars however are not in agreement on the days of fasting and the measurement of the charity. According to the hadith by Ka'āb, the number of days to fast is three and according to Al-Hasan, Ikrimah and Nāfi', the duration is ten days. For the charitable giving measurement Mālik, Al-Shāfí' $\overline{1}$ and Abū Hanī̄fah agree that it has to be given in the amount of two mudd (based on the Prophet's mudd weightage) while Ahmad bin Hanbal suggests that 1 mudd of wheat must be given for every poor person or half of sha' of dates.

Al-Marāghî ${ }^{-12}$ gives the same explanation on the mode of fidyah with additional information that after the revelation of this verse, $\mathrm{Ka}$ 'ab narrated that the prophet commanded on the form of fidyah in three days of fasting or giving charity equivalent to six bushel of dates. A clearer explanation on the measurement of charity in fidyah is clarified by Wahbah al-Zuhayli ${ }^{13}$ who states that the fidyah to be distributed is six bushel of dates with a bushel equals to 2.751 kilogram is given to each poor person. If the charity is given in the form of wheat, the measurement is three bushel and each poor will get half a bushel. Other scholars use faraq measurement whereby a faraq equals to 16rotl. A rotl is 408/ 450gram. Besides that, Abu Yusuf says that the fidyah can be in the form of giving food for the needy during lunch and dinner. Thus, it is concluded that charity can also be given in the form of food or feeding the needy for the purpose of paying the penalty of religious conduct which falls under mandatory charitable giving category.

Another type of voluntary charitable giving is also evident in Surah Yūsuf as follows:

${ }^{11}$ Muḥammad bin Aḥmad al-Anșārī al-Qurțubī, Al-Jāmi li Ahkām al-Qurān, $1: 733$

12 Aḥmad Muṣṭafā al-Marāghī, Tafsīr al-Marāghī (Beirut: Dār al-Fikr, 2001), $1: 179-181$.

13 Wahbah al-Zuhaylī, al-Tafsīr al-Munīr fi al-'Aqīdah wa al-Sharī'ah wa alManhaj (Damascus: Dār al-Fikr, 2003), 1:558- 560. 


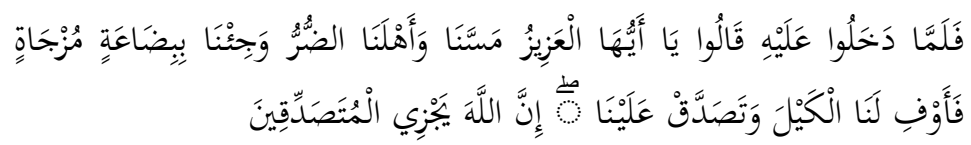

Translation: "So when they entered upon Joseph, they said, "O 'Azeez, adversity has touched us and our family, and we have come with goods poor in quality, but give us full measure and be charitable to us. Indeed, Allah rewards the charitable" ${ }^{, 14}$.

Yūsūf 12:88

According to al-Qurtubi ${ }^{-15}$, the word sadaqah in this verse contains several meanings. The first from Ibn Jurayj, Sa'īd bin Jubayr, as-Suddī and al-Hassan who opine that this word means to give advantage between high and low price. Secondly, to give more than what is deserved as explained by Sufyān bin 'Uyaynah, to 'return our brothers to us' as defined by Ibn Jurayj and to 'forgive us' as posited by Ibn Shajarah. Al-Marāghī elaborates this verse by describing the word sadaqah means as being kind by giving advantage to those who deserved..$^{16}$ Interestingly, this verse does not infer charity to any specific kinds of giving or any form of material gifts but it tends to mean the act of being kind which leads to a more general meaning of charity.

Apart from the word sadaqah, another word also found commonly used in the Quran to convey the command of doing charity is infaq. The term infaq is rooted from the word nafaqa which literally means to spend. Al Marbawi ${ }^{17}$ defines infaq as to spend with planning. Linguistically, infaq refers to any kinds of spending but from the view of Shariah, the concept of $i$ infaq is mostly discussed in the context of spending away to seek pleasure of God and for the benefit and improvement of the society as a whole which includes the donor and the family as found in the following Quranic verses:

\footnotetext{
${ }^{14}$ Abdul Malek Mujahid, Tafsir Ibn Katsir/ Abridged by a Group of Scholars Under the Supervision of Shaykh Safi Ur Rahman al-Mubarakpuri, 5:202

${ }^{15}$ Al-Qurțubī, al-Jami' li Aḥkām al-Qurān, 5:.227-230.

${ }^{16}$ Al-Marāghī, Tafsīr al-Marāghī, 5:18-21

17 Muhammad Idris Abdul Rauf al-Marbawi, Kamus al-Marbawi (Egypt: Mușțafā al-Bābī al-Halabī wa Awlādihi,1929), 336.
} 


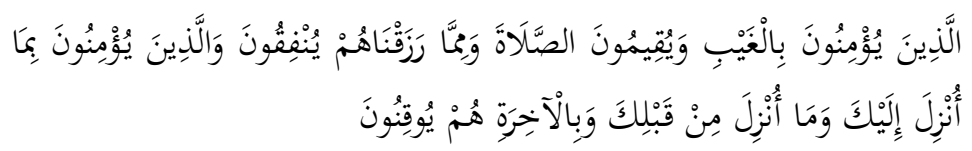

Translation: "Who believe in the unseen, establish prayer, and spend out of what We have provided for them, And who believe in what has been revealed to you, [O Muhammad], and what was revealed before you, and of the Hereafter they are certain [in faith]". ${ }^{18}$

Al-Baqarah 2:3-4

According to Ibn Kathīr ${ }^{19}$ the word infaq in this verse originally refers to the meaning of spending on family and also general spending meant for the sake of getting closer to the Creator in accordance to one's capability before the obligation of zakat. After the zakat obligation is revealed the meaning is replaced with zakat on wealth. Al-Marāghi ${ }^{20}$ explains that infaq in this verse covers both the mandatory spending such as giving to spouse, children and family members and also the voluntary giving which works in purifying the soul. Al-Qurtub ${ }^{-21}$ explains that the word infaq in this verse refers to the act of withdrawing wealth by the hand. Ibn 'Abbās reckons that this word refer to the payment of zakat as it is mentioned together with the obligation of salat (prayer). It is also said that it refers to the nafqah (spending) from a husband to the wife as it is the foremost spending. Abu Qilabah also states that it refers to the mandatory spending to the family while Dahhak opines that as the word zakat is not specifically used, this term refers to the voluntary charitable giving such as offering sacrifice. Thus, it is concluded that this word refers to the general infaq which covers both the mandatory and voluntary charitable giving.

The use of both words sadaqah and infaq is observed in the following indicating that both word are synonymous in meaning.

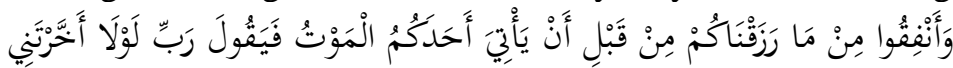

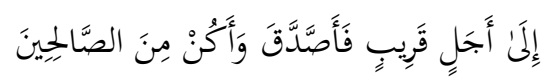

18 Abdul Malek Mujahid, Tafsir Ibn Katsir/ Abridged by a Group of Scholars under the Supervision of Shaykh Safi Ur Rahman al-Mubarakpuri, 1:112-114

${ }^{19}$ Ibn Kathīr, Tafsìr al-Qurān al- 'Ażīm, 1/2:54.

${ }^{20}$ Al-Marāghī, Tafsir al-Marāghī, 1:28-29.

${ }^{21}$ Al-Qurțubī, al-Jami' li Aḥkām al-Qurān, 1:163-177 
Translation: "And spend [in the way of Allah from what We have provided you before death approaches one of you and he says, "My Lord, if only You would delay me for a brief term so I would give Sadaqah from my wealth and be among the righteous" 22 .

Al-Munāfiqūn 63:10

Ibn Kathīr ${ }^{23}$ defines both words infaq and șadaqah as to spend in Allah's cause while al-Qurtub $\mathbf{1}^{-24}$ argues that both words indicate the obligation of mandatory charitable giving and also associated to the obligation of pilgrimage for those who can afford of doing so but postpone it until the time of death and they ask the God for respite; this definition is also shared by Wahbah alZuhayli $^{25}$.

From the discussion, it is found that the word sadaqah and infaq are mostly used to represent the meaning of charity in the Quran which basically refer to the act of spending out of the wealth for the sake of Allah and that there are two major categories of spending for charity which are the mandatory charitable giving and voluntary charitable giving. Although majority of these verses connote the charity to material spending and prove that these two words are synonymous in meaning, a slight difference is detected for the word sadaqah in Surah Yusuf indicating that the word charitable also means to be kind. To explore the other facades of charity in Islam, evidences from the Hadith are also examined in the following section.

\section{Definition of Charity Based on the Hadith}

The following hadith discusses the variety of voluntary spending from freeing a slave and giving to the poor. However giving to the family as the mandatory charitable giving is prioritized and highly rewarded.

\footnotetext{
22 Abdul Malek Mujahid, Tafsir Ibn Katsir/ Abridged by a Group of Scholars under the Supervision of Shaykh Safi Ur Rahman al-Mubarakpuri, 9.:658.

${ }^{23}$ Abdul Malek Mujahid,Tafsir Ibn Katsir/ Abridged by a Group of Scholars under the Supervision of Shaykh Safi Ur Rahman al-Mubarakpuri, 7/8:106107.

${ }^{24}$ Al-Qurțubī, al-Jami' li Aḥkām al-Qurān, 9:368-369.

25 Al-Zuhaylī, al-Tafsìr al-Munìr fì al-'Aqīdah wa al-Sharī'ah wa al-Manhaj, 14:.610-614
} 


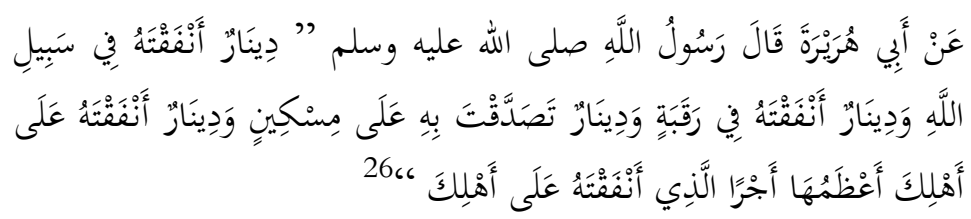

Translation: Abū Hurayrah reported Allah's Messenger as saying: "Of the dinar you spend as a contribution in Allah's path, or to set free a slave, or as a sadaqa given to a needy, or to support your family, the one yielding the greatest reward is that which you spent on your family."

Sadaqah, specifically the voluntary charitable giving also can be done in the form of a will or wasiah as evidently found in the hadith of Șahīh Muslim:

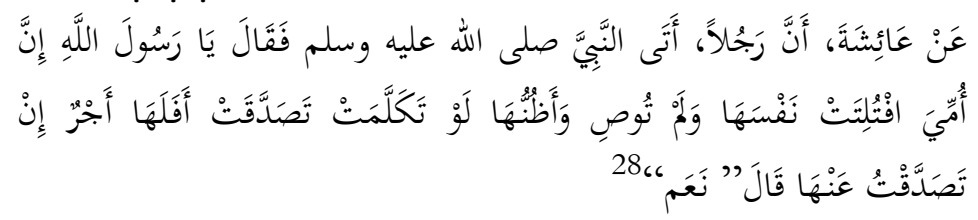

Translation: 'Āisha said that a person came to the Messenger of Allah and said: "My mother died suddenly without having made any will. I think she would have definitely given Sadaqa if she had been able to speak. Would she have a reward if I gave Sadaqa on her behalf? He (the Holy Prophet) said: Yes."

Sadaqah is also given in the form of a gift during the time of Prophet as the Prophet is not entitled to receive a charity, it is regarded as a gift or hadiyah.

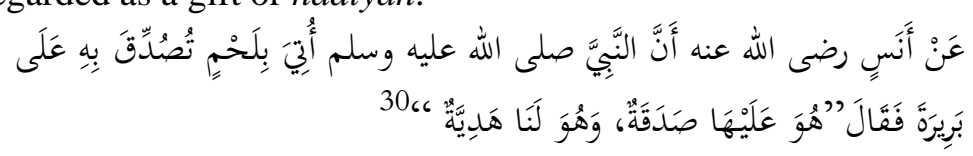

Yaḥyā Ibn Sharaf al-Nawāwī, al-Manhaj fi Sharḥ Șaḥ̄ḥ Muslim Ibn Hajjaj alMusamma Ikhtișāran Sharh Ṣaḥ̄h Muslim (Beirut: Dār al-Khayr, 1999), 7/8/9: 68.

27 Abdul Hamid Siddiqi, Sahih Muslim; Arabic-English (India: Adam Publishers \& Distributors., 1999), 2:91.

28 Al-Nawāwī, al-Manhaj fì Sharh Sạ̄ịh Muslim Ibn Hajjaj al-Musamma Ikhtișāran Sharh Ṣaḥ̄h Muslim, 7/8/9:74

29 Abdul Hamid Siddiqi, Sahih Muslim; Arabic-English, 2:94.

${ }^{30}$ Muhammad bin Ismā‘̄il al-Bukhārī, Șah̄ịhī al-Bukhārī, 1:388. 
Translation: Narrated Anas: Some meat was presented to the Prophet (p.b.u.h) and it had been given to Barira (the freed slave-girl of Aisha) in charity. He said, "This meat is a thing of charity for Barira but it is a gift for us" $" 31$.

The gift is also known as hibah and can be used as an instrument for voluntary charitable giving as found in the hadith that follows:

$$
\begin{aligned}
& \text { عن ابن عباس رضي الله عنهما أن رسول الله صلى الله عليه وسلم قال: }
\end{aligned}
$$

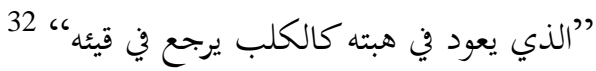

Translation: Ibn 'Abbās (May Allah be pleased with them) said: "The Messenger of Allah said, 'He who gives something (to someone) as a gift and then gets it back (from him or her) is like a dog which eats its own vomit.",33

Other than that, charitable giving also can be carried out in the form of waqf as proven in the parable of 'Umar al-Khattāab, the Prophet's companion who donated his land in Khaybar in the form of waqf in which the possession is still intact but the production from the land is given for charity as described in the hadith below:

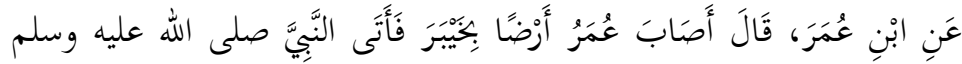

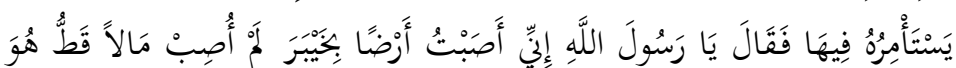

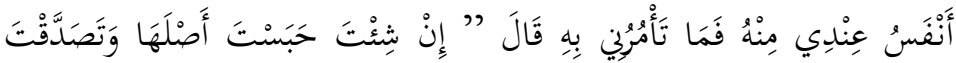

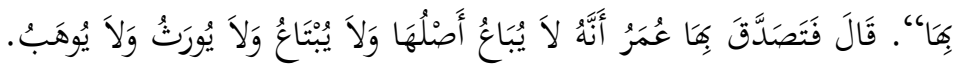

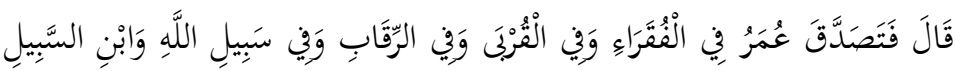

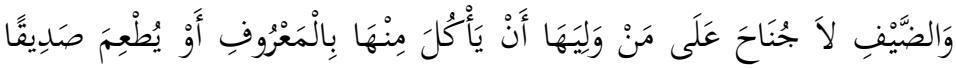

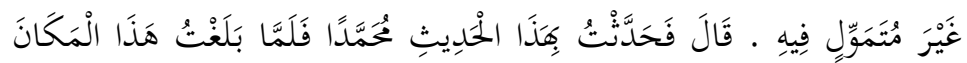

\footnotetext{
31 Mahmood Matraji, The Translation of the Meanings of Sahih al-Bukhari, 2:312.

${ }^{32}$ Al-Bukhārī, Șaḥihh al-Bukhārī, 2:226

${ }^{33}$ Mahmood Matraji, The Translation of the Meanings of Sahih al-Bukhari, 3:441
} 


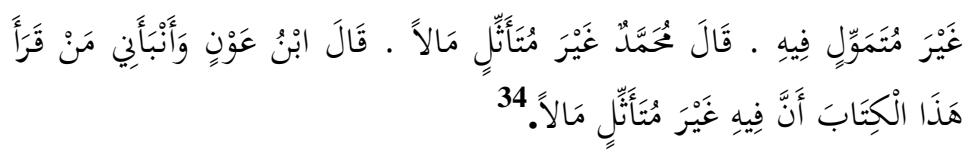

Translation: Ibn Umar reported: Umar acquired a land at Khaibar. He came to Allah's Apostle and sought his advice in regard to it. He said: "Allah's Messenger, I have acquired land in Khaibar. I have never acquired property more valuable for me than this, so what do you command me to do with it? Thereupon he (Allah's Apostle) said: If you like, you may keep the corpus intact and give its produce as Sadaqa. So 'Umar gave it as Sadaqa declaring that property must not be sold or inherited or given away as gift. And Umar devoted it to the poor, to the nearest kin, and to the emancipation of slaves, aired in the way of Allah and guests. There is no sin for one, who administers it if he eats something from it in a reasonable manner, or if he feeds his friends and does not hoard up goods (for himself). He (the narrator) said: I narrated this hadith to Muhammad, but as I reached the (words)" without hoarding (for himself) out of it." he (Muhammad' said: "without storing the property with a view to becoming rich". Ibn "Awn said: He who read this book (pertaining to Waqf) informed me that in it (the words are) "without storing the property with a view to becoming rich" 35 .

Interestingly, charitable giving in hadith is very wide in meaning as according to the Prophet, every good deed is considered as charity.

$$
\begin{aligned}
& \text { عَنْ جحابِرِ بْنِ عَبْدِ اللَّهِ ـ رضى الله عنهما عَنِ النَّبِّ صلى الله عليه وسلم قَالَ }
\end{aligned}
$$

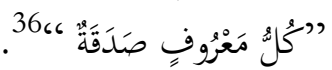

Narrated Jābir bin 'Abd Allah: The Prophet said "Enjoining, all that is good is a Sadaqa" 37 .

The encouragement to do charity is subjected to all Muslims in every way they are able to do so. The Muslims must work to

34 Al-Nawāwī, al-Manhaj fì Sharh Șah̄ị Muslim Ibn Hajjaj al-Musamma Ikhtișāran Sharh Sahīh Muslim, 10/11/12 :253-254.

${ }_{35}$ Abdul Hamid Siddiqi, Sahih Muslim; Arabic-English, 3:83

${ }^{36}$ Al-Bukhārī, Sahih al-Bukhari, 4:107.

${ }^{37}$ Mahmood Matraji, The Translation of the Meanings of Sahih al-Bukhari, 8:57. 
earn and contribute to the charity, if they are not able to do so, they are encouraged to help the needy with their might, if they are not able to do so, they have to bring people to do good deeds and if they are not able to do so they have to refrain themselves from doing bad things. All these are categorized as charity which means charity should not only be done using material means but also other means such as manpower and good deeds.

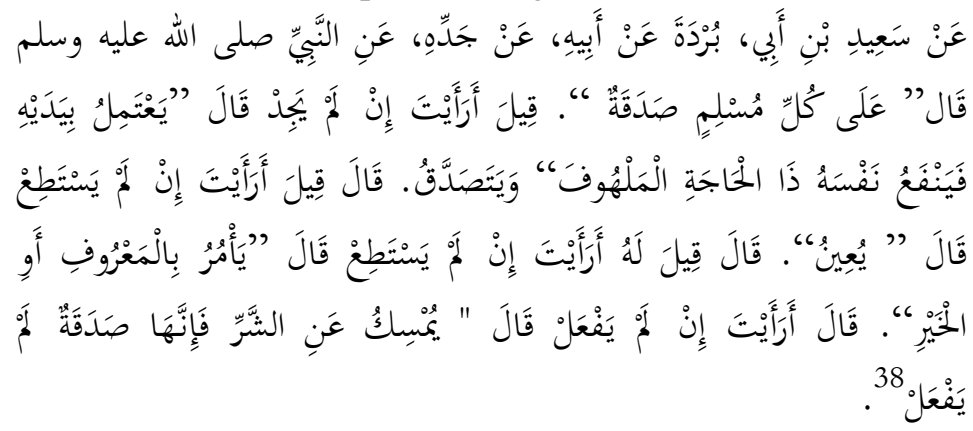

Translation: Sa'īd bin Abū Burda reported on the authority of his grandfather that the Messenger of Allah said: "Giving of Sadaqa is essential for every Muslim. It was said (to him): What do you say of him who does not find (the means) to do so? He said: Let him work with both his hands, thus doing benefit to himself and give Sadaqa. It was said to him: What about him who does not have (the means) to do so? He said: Then let him assist the needy, the aggrieved. It was said: What do you say of one who cannot even do this? He said: Then he should enjoin what is reputable or what is good. He said: What about him if he cannot do that? He (the Holy Prophet) said: He should then abstain from evil, for verify that is Sadaqa on his behalf, ${ }^{39}$.

Another example of charity deed is to planting trees which is rewarded for everything eaten out of it, everything stolen out of it and everything eaten out of it by animals.

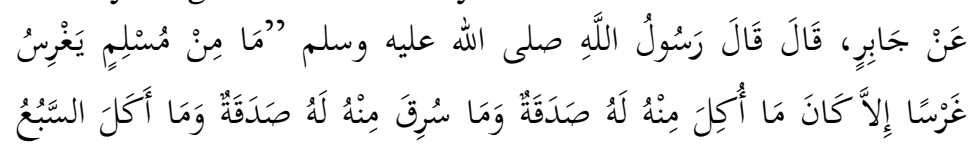

38 Al-Nawāwī, al-Manhaj fī Sharh Șaḥịh Muslim Ibn Hajjaj al-Musamma Ikhtișāran Sharh Șaḥ̄ḥ Muslim, 7/8/9: 78.

${ }^{39}$ Abdul Hamid Siddiqi, Sahih Muslim; Arabic-English, 2:96 


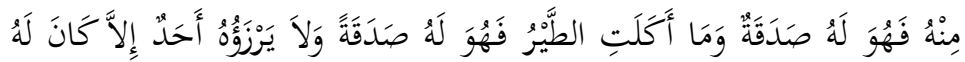

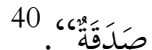

Translation: Jābir (Allah be pleased with him) reported Allah's Messenger as saying: "Never does a Muslim plants a tree except that he has the reward of charity for him, for what is eaten out of that is charity; what is stolen out of that, what the beasts eat out of that, what the birds eat out of that is charity for him. In short, none incurs a loss to him but it becomes a charity on his part."

Therefore, from the discussion it is concluded that charitable giving can be done in any means not only restricted to material giving but also covers the nonmaterial aspects such as doing good towards others.. It is also discovered from the discussion that many instruments can be used to conduct charitable giving such as wasiah, hibah, hadiah and waqf. The findings from the Quran and Hadith lead to the formation of charitable giving classification below:

Mandatory Charitable Giving

Sadaqah

(Charity)

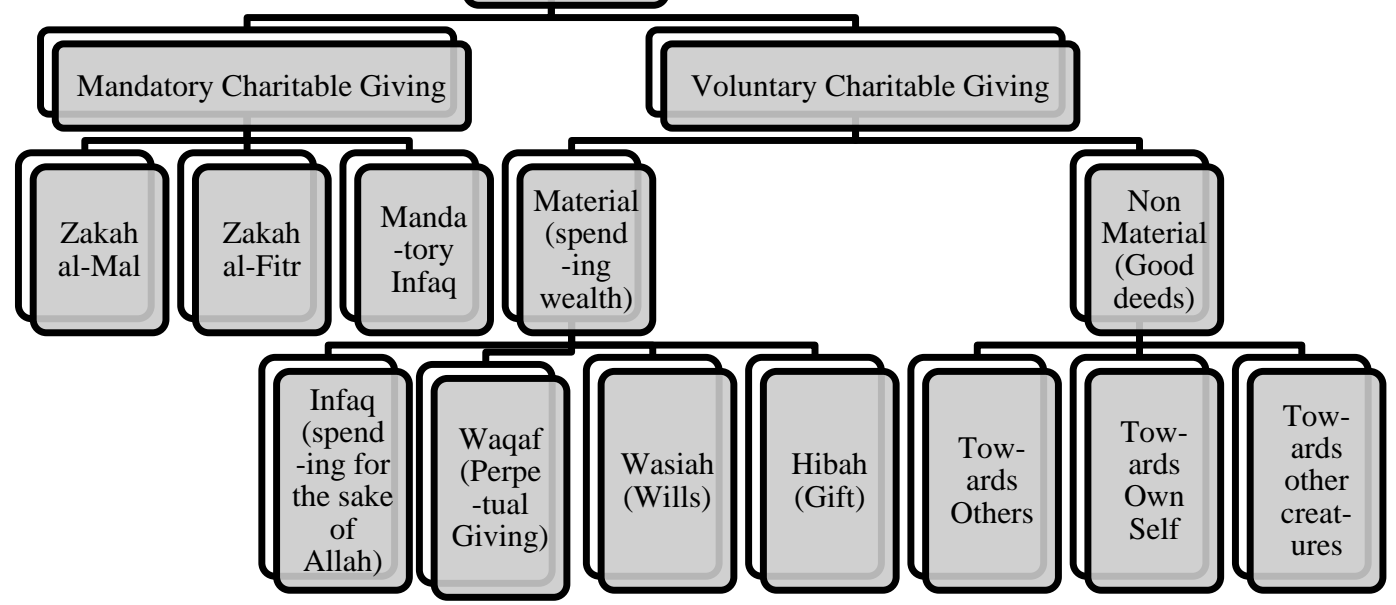

Figure 1: Classification of Charitable Giving

40 Al-Nawāwī, al-Manhaj fi Sharh Șaḥịh Muslim Ibn Hajjaj al-Musamma Ikhtiṣāran Sharh Șaḥịh Muslim, 10:164.

${ }^{41}$ Abdul Hamid Siddiqi, Sahih Muslim; Arabic-English, 1:31. 


\section{The Rules of Voluntary Charitable Giving in Islam}

As the rules of mandatory charitable giving has been widely discussed, the rules of voluntary charitable giving has been left nearly unexplored. To conduct a valid voluntary charitable giving, four important requirements which are the donor, the recipient, the gift and the intention ${ }^{42}$ must be fulfilled to conduct a valid charitable giving.

\section{A.The Donor (al-Mutașaddaq)}

The donor is the giver who spends his own wealth to conduct charitable giving and must have sanity, ability to think, reached puberty and qualified to do transaction. ${ }^{43}$ This quality of donor is termed as al-ahliyyat which means the competence and legal capacity of a person to acquire rights and accept duties. According to Wahbah al-Zuhayli ${ }^{-44}$, there are two types of al-ahliyyah in muamalat which are;

i) Ahliyyah al-Wujub (the capacity to acquire rights and obligations or known as the receptive legal capacity)

ii) Ahliyyah al-Ada' (the capacity to execute or known as the active legal capacity)

\section{B.The Recipients (al-Mutașaddaq 'alayh)}

The recipient is the person or the party that receives donation from the other ${ }^{45}$. There are many categories of recipients of charity as found in the Quran. The discussion of the recipient categories is as follows:

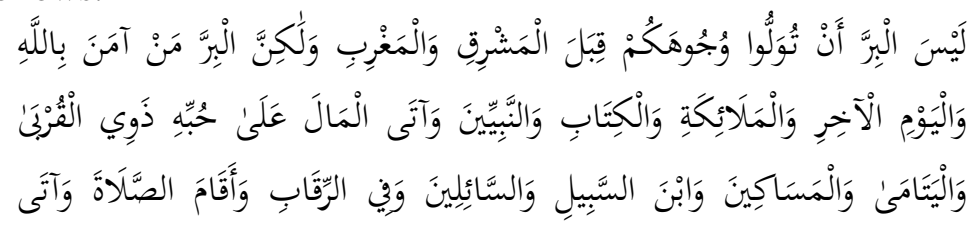

${ }^{42}$ Al-Jumu'ah Ali Ibn Muhammad, Mu'jam al-Muṣtalahāt al-Iqtisadiyyah wa alIslāmiyyah (Riyadh: Maktabah al-'Ubaykat, 2000), 347

${ }^{43}$ Al-Jumu'ah Ali Ibn Muḥammad. Mu'jam al-Muṣtalahāt al-Iqtisadiyyah wa alIslāmiyyah, 348.

${ }^{44}$ Wahbah al-Zuhaylī, al-Fiqh al-Islāmī wa Adillatuhu (Damascus: Dār al-Fikr, 1989), 116.

${ }^{45}$ Al-Zuhaylī, al-Fiqh al-Islāmī wa Adillatuhu, 348. 


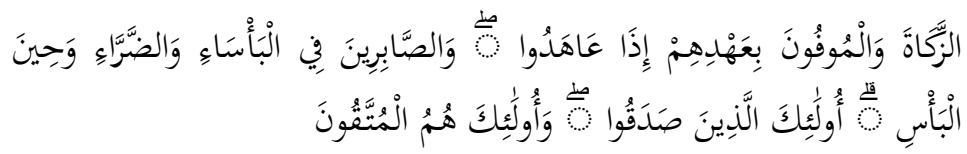

Translation: "Righteousness is not that you turn your faces toward the east or the west, but [true] righteousness is [in] one who believes in Allah, the Last Day, the angels, the Book, and the prophets and gives wealth, in spite of love for it, to relatives, orphans, the needy, the traveler, those who ask [for help], and for freeing slaves; [and who] establishes prayer and gives zakah; [those who] fulfill their promise when they promise; and [those who] are patient in poverty and hardship and during battle. Those are the ones who have been true, and it is those who are the righteous"

Al-Baqarah 2:177

This verse explains the term birr refers to obedience to Allah by following all His legislations. Ibn Kathīr elaborates this verse by stating that a person who gives away when he is also in need poses a higher degree of giving and that giving should be made to $^{47}$ :

i. Kinsfolk or relatives who are in need.

ii. The orphans who are children having lost their fathers and still need governance from others.

iii. The poor who do not have enough basic necessities such as food, clothing or home. (al-Miskin)

iv. The wayfarers who are travelers in need of money who must be helped to get him return to his homeland and the guest hosted by Muslims is also included in this definition. (Ibn alSabìl)

v. The beggars who beg people for charity. (as-Sä'il)

vi. The servants by setting them free. (al-Riqab)

Al-Qurtubu $1^{-48}$ posits that spending on the mentioned groups of people is not considered as spending on zakat but it is the obligation of spending the wealth which is called mal al birr (spending on good deed). Although a person has already performed the mandatory charitable giving (zakat), help should

\footnotetext{
${ }^{46}$ Abdul Malek Mujahid, Tafsir Ibn Katsir/ Abridged by a Group of Scholars Under the Supervision of Shaykh Safi Ur Rahman al-Mubarakpuri, 1:478.

47 Ibn Kathīr, Tafsīr al-Qurān al- 'Aż̄im, 1/ 2:.268-271.

${ }^{48}$ Al- Qurțubī, al-Jāmi’ li Aḥkām al-Qurān, 1:628-634.
} 
also be given to the person in need especially from the aforementioned group. Al-Marāghî ${ }^{-49}$ elaborates that to help these people in need are not restricted by time or amount but solely depends on the giver. However it is the obligation of Muslim to help these people which eventually strengthens the relationship among the people in the society.

Furthermore, it is permissible to give to anybody in need even the non Muslims as explained in the following verse;

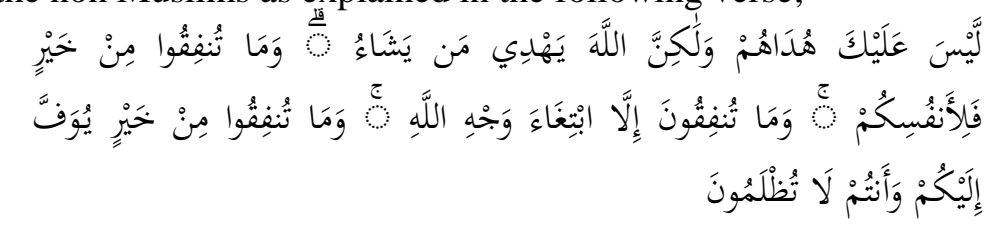

Translation: "Not upon you, [O Muhammad], is [responsibility for] their guidance, but Allah guides whom $\mathrm{He}$ wills. And whatever good you [believers] spend is for yourselves, and you do not spend except seeking the countenance of Allah. And whatever you spend of good - it will be fully repaid to you, and you will not be wronged"50.

This verse indicates the permissibility to give charity to the non Muslims as according to Ibn Kathīr ${ }^{51}$, based on the opinion of Hassan al-Bașrī, the charity given for the sake of Allah will not be asked on who are the recipients whether they are the righteous, deserving the help, good or evil and so on as the reward will be given for his good intention. Al-Qurtubi ${ }^{-52}$ clarifies that this verse is revealed after the Prophet denies the charitable giving for a Jew as he wishes that the Jew will be drawn to Islam and later Allah commands that giving to non Muslim is permissible and that it is not the obligation to force anyone to embrace Islam. Most of scholars opine that only voluntary charitable giving can be given to the non Muslims but not the mandatory charitable giving or zakat as suggested by Ibn al-Mundhīr.

\footnotetext{
49 Al-Marāghī, Tafsir al-Maraghiy, 1:156-160.

50 Abdul Malek Mujahid, Tafsir Ibn Katsir/ Abridged by a Group of Scholars Under the Supervision of Shaykh Safi Ur Rahman al-Mubarakpuri, 2:63

${ }^{51}$ Ibn Kathīr, Tafsīr al-Qurān al-Ażìm, 1 :423-427.

${ }^{52}$ Al-Qurțubī, Al-Jāmi ‘ li Ahkām al-Qurān, 2:291-297
} 
Al-Marāghi ${ }^{53}$ states that the benefit of giving will return to the giver and that Allah promises that the giving will not be left wasted and it will be fully rewarded. Wahbah az-Zuhayli ${ }^{54}$ further elaborates that the benefit of giving for charity will be gained by the giver and that the donor must conduct the giving solely to attain the pleasure of the God not concerning the effect of the donation to the recipients. This opinion is based on the hadith below that shows charity can be given to anyone as long it is sincerely done for the sake of Allah and the result of giving is not determined by the giver.

$$
\begin{aligned}
& \text { وعن أبي هريرة رضي الله عنه أن رسول الله صلى الله عليه وسلم قال: "قال } \\
& \text { رجل لأتصدقن بصدقة، فخرج بصدقته، فوضعها في يد سارق، فأصبحوا } \\
& \text { يتحدثون: تصدق على سارق! فقال: اللهم لك الحمد لأتصدقن بصدقة، } \\
& \text { فخرج بصدقته، فوضعها في يد زانية؟! فأصبحوا يتحدثون: تصدق على زانية }
\end{aligned}
$$

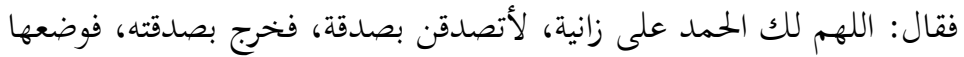

$$
\begin{aligned}
& \text { في يد غني, فأصبحوا يتحدثون! تصدق الليلة على غني, فقال: اللهم لك }
\end{aligned}
$$

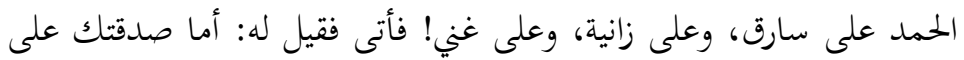

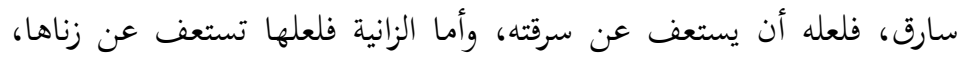

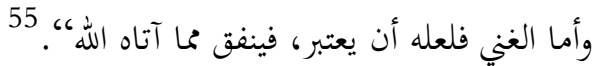

Translation: Abū Hurayrah (May Allah be pleased with him) said: The Messenger of Allah said: "A man (from amongst the people before you) said: 'Indeed! I will give in charity". So he took his Sadaqah out and placed it in a thief's hand. In the morning the people were talking (about this incident) and saying: 'S Sadaqah was given to a thief last night'. The man said: 'O Allah! Praise be to You. I have given Sadaqah to a thief. Indeed, I will give in charity!' So he took his Șadaqah out and he placed it in a prostitute's hand. In the morning the people were talking (about this incident) and saying:

\footnotetext{
${ }^{53}$ Al-Marāghī, Tafsīr al-Marāghī, 1:.278-280.

${ }^{54}$ Wahbah al-Zuhaylī, al-Tafsìr al-Munīr fì al-'Aqīdah wa al-Sharī'ah wa alManhaj, 2:78-89.

${ }^{55}$ Al-Bukhārī, Sahih al-Bukhari, 1:367-368.
} 
'Șadaqah was given to a prostitute last night'. On hearing this, the man said: 'Praise be to You, O Allah! I gave Șadaqah to a prostitute. Indeed, I will give in charity!' So he took his Sadaqah out and placed it in a rich man's hand. In the morning the people were talking (about this incident) and saying: 'Șadaqah was given to a rich man last night'. The man said: 'O Allah! Praise be to You (for helping me) give charity to a thief, a prostitute and a rich man'. Then he had a dream in which he was told that his Șadaqah to the thief might result in his refraining from his theft, his Sadaqah to the prostitute might help her abstain from her immorality, and his Șadaqah to the rich man might help him pay heed and spend from what Allah had bestowed upon him"

Although the criteria of the recipient is not clearly specified and the term of beggar is general that includes all people in need that transcends beyond the race, religion and others, the following verse expresses that the priority in giving charity must be given to the needy person who does not manifest his hardship by begging the help from others. The characteristic of the person that deserved the help is further described in the following verse:

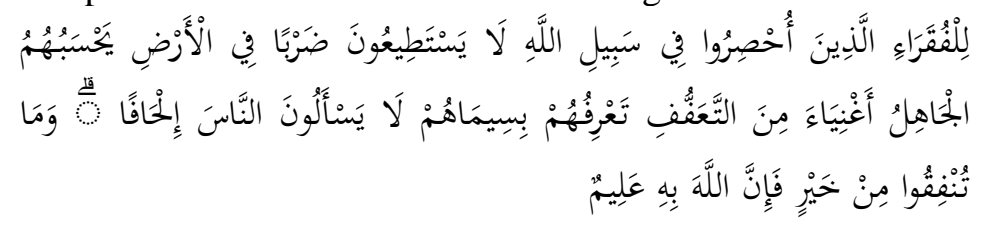

Translation: "[Charity is] for the poor who have been restricted for the cause of Allah, unable to move about in the land. An ignorant [person] would think them self-sufficient because of their restraint, but you will know them by their [characteristic] sign. They do not ask people persistently [or at all]. And whatever you spend of good - indeed, Allah is Knowing of it" ${ }^{, 57}$.

Al-Baqarah 2:273

\footnotetext{
56 Mahmood Matraji,The Translation of the Meanings of Sahih al-Bukhari, 2:274-275

57 Abdul Malek Mujahid, Tafsir Ibn Katsir/ Abridged by a Group of Scholars Under the Supervision of Shaykh Safi Ur Rahman al-Mubarakpuri, 2:62.
} 
According to Ibn Kathīr ${ }^{58}$ this verse describes the characteristics of the poor who deserved to be given charity, who;

i. is fighting in the way of Allah, giving all his strength in Jihad and seeking the pleasure of Allah SWT,

ii. does not have the capability to work due to illness or others,

iii. does not want to beg for keeping his or her dignity until no one knows of his/ her misery

iv. has a special characteristic only known by sincere believer such as being tawaddhu' without deliberately revealing the physical state of a needy person.

$\mathrm{v}$. is not begging as forcefully as the usual beggars do.

Al-Qurtubi ${ }^{-59}$ also explains on the aforementioned characteristics by expanding the discussion on the fifth criterion which is the condition of asking for help which is not forcefully. On the contrary, some scholars such as al-Tabarī and al-Zujāj specified that these people will not be begging at all as they avoid the worldly affairs. Imam Ahmad says that begging is allowed if someone is under extreme difficulty although restricting himself from begging is better for him as one must surrender himself to God. Thus it is ruled out that begging is allowed under critical condition and the person asked must be chosen form the pious. However, if something is given not out of begging then it must be accepted as a blessing from the God. Moreover, a needy person is allowed to beg not more than three times and if a person is asked to help and he is capable of doing so, he is obliged to fulfill the request.

It is also recorded that it is haram or unlawful for a wealthy or a person who possesses any kinds of wealth to beg which is also supported by Al-Marāghî ${ }^{60}$. Nevertheless, there are exceptions to give șadaqah to rich man as according to hadith narrated by Ata ibn Yasar who fights for Allah's cause, acts as the amil or the sadaqah collector, a debtor, a rich man who gives charity with his own money and a rich man who has been giving charity to his neighbor and is given a gift or sadaqah as a return as explained in the hadith below:

\footnotetext{
${ }^{58}$ Ibn Kathīr, Tafsīr al-Qurān al-Azìm, 1/ 2:423-427

${ }^{59}$ Al-Qurțub̄i, al-Jāmi ' li Ahkām al-Qurān, 2: 291-297.

${ }^{60}$ Al-Marāghī, Tafsīr al-Marāghī, 1:278-280
} 


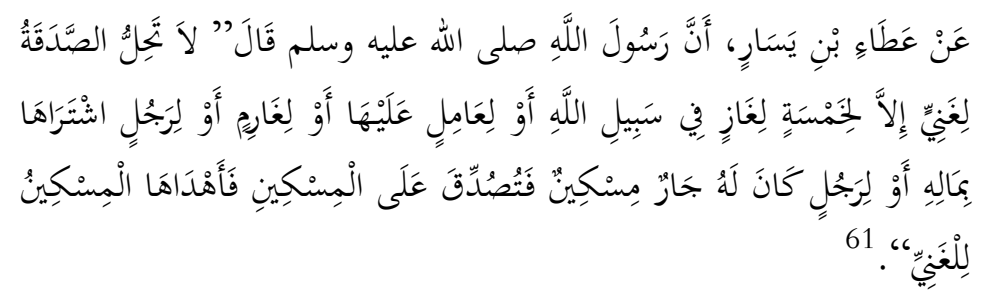

Translation: Narrated 'Ațầ' ibn Yasar: The Prophet said: Sadaqah may not be given to rich man, with the exception of five classes: One who fights in Allah's path, or who collects it, or a debtor, or a man who buys it with his money, or a man who has a poor neighbour who has been given șadaqah and gives a present to the rich man $^{62}$.

\section{C.The Gift (al-Mutașaddaq Bih)}

The third component of giving is the gift which is given to the recipients in the form of money, things or services. It is encouraged to give things that are loved and favoured as in mentioned in the following verse:

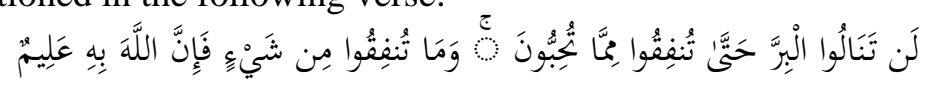

Translation: "Never will you attain the good [reward] until you spend [in the way of Allah ] from that which you love. And whatever you spend - indeed, Allah is Knowing of it"63.

Āli 'Imrān 3:92

Ibn Kathīr ${ }^{64}$ elaborates that the word al-Birr refers to paradise which means one will attain the reward of paradise if he spends in charity for the sake of Allah of the things that he most loves. AlQurtub $^{-65}$ reports that scholars are in different views on the meaning of al-Birr in this verse. Some companions of the Prophet like Anas and Abu Talhah associate it to the meaning of the ultimate charity. While Ibn Mas'ūd, Ibn 'Abbās, 'Ața', Mujāhid, 'Amr bin Maymūn and al-Suddī define it as the reward of

\footnotetext{
${ }^{61}$ Abī Dawūd Sulaymān Ibn al-Ash'ath al-Sijistān̄̄, Sunan Ab̄̄ Dawūd (Beirut: Dār al-Fikr,1999), 2:202.

${ }^{62}$ Yaser Qadhi, English Translation of Sunan Abu Dawud (Riyadh: Darussalam, 2008), 2:288.

63 Abdul Malek Mujahid, Tafsir Ibn Katsirl Abridged by a Group of Scholars Under the Supervision of Shaykh Safi Ur Rahman al-Mubarakpuri, 2:.210.

${ }^{64}$ Ibn Kathīr, Tafsir al-Quran al-Azim, 1 /2:.54-55.

${ }^{65}$ Al-Qurțubī, al-Jāmi ‘ li Ahkām al-Qurān, 3:495-496
} 
paradise. Other scholar such as Athiyah al-Awfa describes it as the obedience.

Furthermore, the allocation of giving is explained in the Quran as stated in the following verse that one should spend in charity from the spare of the family needs.

$$
\text { وَيَنْأَلُونَكَ مَاذَا يُنْفِقُونَ قُلِ الَْفْوَ }
$$

Translation: "And they ask you what they should spend. Say, "The excess [beyond needs]"

Al-Baqarah 2:219

Ibn Kathīr ${ }^{67}$ states that it is summoned that the basic need of a family must be fulfilled and the surplus of it can be spend on charity. According to al-Qurtubi ${ }^{-68}$, the word al-'afw means something that is easy, extra, and can be given away without heavy heart which means to give something that will not cause hardship to the giver. Al-Ḥasan, Qatādah, Athar, al-Suddī, alQarzhi Muhammad bin Ka'ab, Ibnu Laila and Ibn 'Abbās suggest that this word means the excess from the family need. AlMarāgh $\overline{1}^{69}$ specifies that the form of giving here is the voluntary giving as the amount of giving is decided by the giver which is the surplus from what is needed.

It is also reminded in the Quran that the gifts to be given to the recipients of charity must come from a good and permissible source as stated in the following verse:

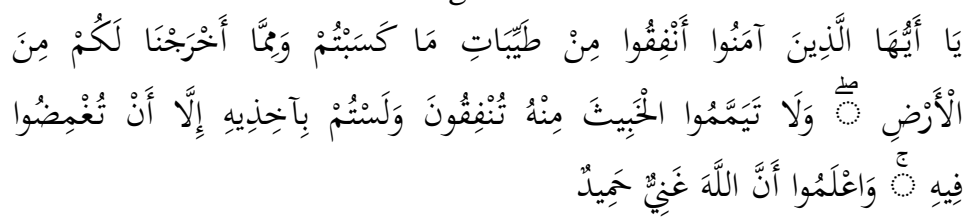

Translation: "O you who have believed, spend from the good things which you have earned and from that which We have produced for you from the earth. And do not aim toward the defective therefrom, spending [from that] while you would

\footnotetext{
${ }^{66}$ Abdul Malek Mujahid, Tafsir Ibn Katsir/ Abridged by a Group of Scholars Under the Supervision of Shaykh Safi Ur Rahman al-Mubarakpuri, 1:607.

${ }^{67}$ Ibn Kathīr, Tafsīr al-Qurān al-Ażìm, 1 /2:333-336.

68 Al-Qurțubi, al-Jāmi “li Aḥkām al-Qurān, 2:38-58.

${ }^{69}$ Al-Marāghī, Tafsìr al-Marāghī, 1:203-210.
} 
not take it [yourself] except with closed eyes. And know that Allah is Free of need and Praiseworthy"70.

Al-Baqarah 2:267

Ibn Kathīr ${ }^{71}$ concludes that the source of charity must purely and honestly earned. This includes the things or food to be given away must also be in good condition. This verse was revealed after the Ansar had been found to mix between good ripe dates with less good quality dates for charity. It is also explained in this verse that the charity is not for Allah as He is free from needing anything but the charity is for the needy ones. Al-Qurtubī opines that not only the source of giving must be good and permissible, Allah SWT also prohibits the giving of unwanted things which are not favoured by anyone as stated by al-Qurțub $\overline{1}^{72}$, Al-Marāghī ${ }^{73}$ and Wahbah al-Zuhayli ${ }^{74}$.

\section{D.Intention (an-Niah)}

As charitable giving is meant for the sake of God, intention plays an important role to determine whether the act becomes an ibadah (religious deed) or not. Thus good intention is very much highlighted in this kind of giving as prescribed in the verse as follows:

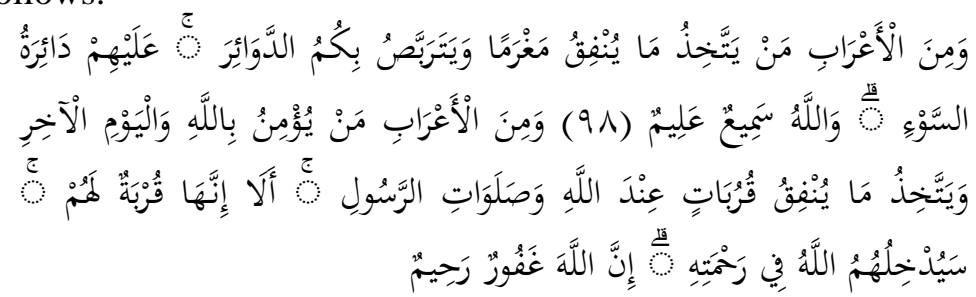

Translation: "And among the bedouins are some who consider what they spend as a loss and await for you turns of misfortune. Upon them will be a misfortune of evil. And Allah is Hearing and Knowing (98)But among the bedouins are some who believe in Allah and the Last Day and consider

\footnotetext{
${ }^{70}$ Abdul Malek Mujahid, Tafsir Ibn Katsir/ abridged by a group of Scholars under the Supervision of Shaykh Safi Ur Rahman al-Mubarakpuri, 2:54

${ }^{71}$ Ibn Kathīr, Tafsìr al-Qurān al-Ażìm, 1/ 2:419-422.

${ }^{72}$ Al-Qurțubī, al-Jāmi 'li Ahkām al-Qurān, 2 : 274-281.

${ }^{73}$ Al-Marāghī, Tafsīr al-Marāghī 1:273-274

74 Al-Zuhaylī, al-Tafsīr al-Munīr fì al-'Aqīdah wa al-Sharī'ah wa al-Manhaj, 2:.63-68
} 
what they spend as means of nearness to Allah and of [obtaining] invocations of the Messenger. Unquestionably, it is a means of nearness for them. Allah will admit them to His mercy. Indeed, Allah is Forgiving and Merciful (99)",75.

Al-Tawbah 9:98-99

This verse describes the attitude of some Arabs of Bedoiuns who regard charitable giving as a loss and a waste and they conduct the giving for the sake of showing off and to protect themselves from the law. Allah proclaims that this kind of giving is useless and does not benefit the doer in any ways. While there are some Bedoiuns who sincerely spend in charity for the sake of Allah and to receive prayers from the Prophet, the act of giving by them is acknowledged and accepted by Allah and rewarded with His blessings ${ }^{76}$.

Spending in charity also must be sincerely done in the sense that no reward is expected to be returned as stated in verse as follows:

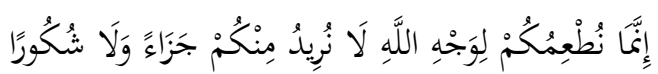

Translation: "[Saying], "We feed you only for the countenance of Allah. We wish not from you reward or gratitude" ${ }^{, 77}$.

Al-Insān 76:9

According to the commentaries by Ibn Kathīr ${ }^{78}$, Al-Marāgh ${ }^{-79}$ and al-Zuhayli ${ }^{80}$, this verse describes among the deeds of a righteous which will be rewarded by Allah is to feed the needy for the sake of Allah without expecting any return from the receiver nor expression of gratitude from them as it is done sincerely for seeking the pleasure of the God and for fear of the judgement day.

75 Abdul Malek Mujahid, Tafsir Ibn Katsir/ Abridged by a Group of Scholars Under the Supervision of Shaykh Safi Ur Rahman al-Mubarakpuri, 4:500.

${ }^{76}$ Ibn Kathīr, Tafsīr al-Qurān al-Azìm, 3/4:138-139

77 Abdul Malek Mujahid, Tafsir Ibn Katsir/ Abridged by a Group of Scholars Under the Supervision of Shaykh Safi Ur Rahman al-Mubarakpuri, 10:286.

${ }^{78}$ Ibn Kathīr, Tafsīr al-Qurān al-Az̄ìm, 7/8:225-227.

${ }^{79}$ Al-Marāghī, Tafsīr al-Marāghī, 10:209-211

${ }^{80}$ Al-Zuhaylī, al-Tafsìr al-Munìr fì al-'Aqīdah wa al-Sharī'ah wa al-Manhaj, 15:306-315 
Since the emphasis of intention is greatly put on charity spending, some acts that nullify the charity are also discussed in several verses of the Quran in Surah al-Baqarah:

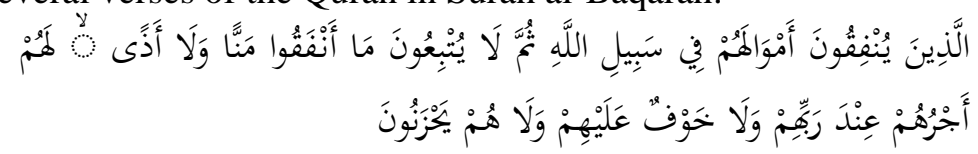

Translation: "Those who spend their wealth in the way of Allah and then do not follow up what they have spent with reminders [of it] or [other] injury will have their reward with their Lord, and there will be no fear concerning them, nor will they grieve" $"$.

Al-Baqarah 2:262

This verse contains a warning from Allah SWT on the deeds that can nullify the charity by reminding people who receive the charity about it in words or actions. Ibn Kathīr ${ }^{82}$ explains that the acceptable charitable giving based on the opinion by al-Mawridī, is done not by expecting any return or thanking from the receiver and also free from mentioning or informing others about it as doing so will hurt the feeling of the receiver. The word al-Mann means to remind people of your own kindness and brag about it to the extent of causing harassment to the receiver while al-Aza means to hurt the recipient of charity in harsh words ${ }^{83}$.

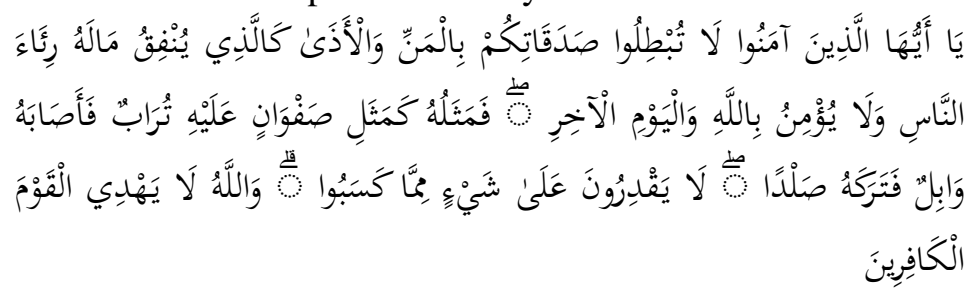

Translation: "O you who have believed, do not invalidate your charities with reminders or injury as does one who spends his wealth [only] to be seen by the people and does not believe in Allah and the Last Day. His example is like that of a [large] smooth stone upon which is dust and is hit by

\footnotetext{
${ }^{81}$ Abdul Malek Mujahid, Tafsir Ibn Katsir/ Abridged by a Group of Scholars Under the Supervision of Shaykh Safi Ur Rahman al-Mubarakpuri, 2:46.

${ }^{82}$ Ibn Kathīr, Tafsīr al-Qurān al-Az̄ìm, 1/ 2:.416-417.

83 A-Zuhaylī, al-Tafsìr al-Munīr fì al-'Aqīdah wa al-Sharī'ah wa al-Manhaj, 2:44-55.
} 
a downpour that leaves it bare. They are unable [to keep] anything of what they have earned. And Allah does not guide the disbelieving people" ${ }^{, 4}$.

Al-Baqarah 2:264

The act of giving is invalidated trough the act of reminding people of the deed and showing off to gain publicity and popularity. Giving charity in pursuit of gaining publicity and popularity nullifies the act like it has never been done. Allah SWT describes this deed like dust on a hard and slippery stone that is completely washed out in a pouring rain ${ }^{85}$. However, charity act is not obligated to be done in anonymity to be accepted by the God as there are many verses in the Quran which discuss the act of doing the charity openly or anonymously. Surah al-Ra'd verse 22 implies that charitable giving can be done both openly and secretly.

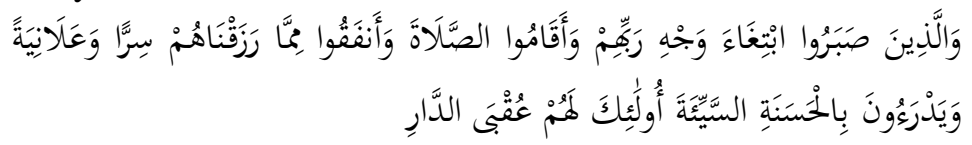

Translation: "And those who are patient, seeking the countenance of their Lord, and establish prayer and spend from what We have provided for them secretly and publicly and prevent evil with good - those will have the good consequence of [this] home"

Al-Ra'd 13:22

Ibn Kathīr ${ }^{87}$ classifies the quality of the blessed ones who are promised with heaven based on this verse and one of the qualities is those who spend the mandatory spending and the voluntary spending at all conditions; openly or secretly and times; day or night. Similarly al-Marāgh $\overline{1}^{-88}$ also opines that the spending includes both the mandatory and voluntary which is done openly or secretly, during day or night. However al-Qurțubi ${ }^{-89}$ explains

\footnotetext{
${ }^{84}$ Abdul Malek Mujahid, Tafsir Ibn Katsir/ Abridged by a Group of Scholars Under the Supervision of Shaykh Safi Ur Rahman al-Mubarakpuri, 2:47.

${ }^{85}$ Al-Marāghī, Tafsīr al-Marāghī 1:268-271.

${ }^{86}$ Abdul Malek Mujahid, Tafsir Ibn Katsir/ Abridged by a Group of Scholars Under the Supervision of Shaykh Safi Ur Rahman al-Mubarakpuri, 5: 267.

${ }^{87}$ Ibn Kathīr, Tafsīr al-Qurān al-'Ażīm, 3 /4:314.

${ }^{88}$ Al-Marāghī, Tafsìr al-Marāghī, 5:54-56.

${ }^{89}$ Al- Qurțubī, Al-Jāmi' li Aḥkām al-Qurān, 5:279-283
} 
that the spending refers to the mandatory charitable giving as according to Ibn 'Abbās.

Further explanation on the anonymity in giving is presented in Surah al-Baqarah verse 271.

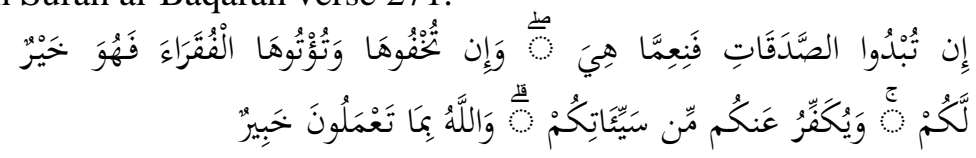

Translation: "If you disclose your charitable expenditures, they are good; but if you conceal them and give them to the poor, it is better for you, and He will remove from you some of your misdeeds [thereby]. And Allah, with what you do, is [fully] Acquainted" $"$.

Al-Baqarah 2:271

This verse explains that charity done openly is good as it can be an exemplary to the society. However, charity in anonymity is better as it avoids the act of bragging and erases the sins ${ }^{91}$. Hasan opines in Tafsìr al-Qurtubi that conducting the mandatory charitable giving in public is better and for voluntary giving, secrecy is better. Ibn Abbas reveals that Allah rewards a concealed noble deed up until 70 times and that the hidden mandatory charitable giving is rewarded 25 times higher than doing it openly. This is to avoid the feeling of riya' or boastfulness. ${ }^{92}$

\section{The Roles of Charitable Giving in the Economy}

Charitable giving from the economic perspective is deemed to be an effective tool to accomplish the objective of optimal redistribution of resources and goods which eventually impact positively on social welfare that has also been the focus of the theory of welfare economics. This due to its nature which has a growing impact to the wealth of the donor as described in the Quran in Surah al-Baqarah:

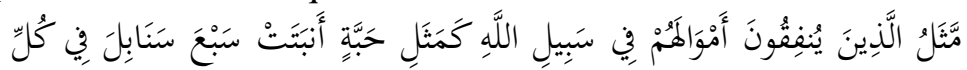

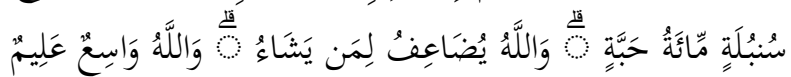

\footnotetext{
${ }^{90}$ Abdul Malek Mujahid, Tafsir Ibn Katsir/ Abridged by a Group of Scholars Under the Supervision of Shaykh Safi Ur Rahman al-Mubarakpuri, 2:60.

${ }^{91}$ Al-Zuhaylī, al-Tafsìr al-Munìr fì al-'Aqīdah wa al-Sharī'ah wa al-Manhaj, 2:72-78.

${ }^{92}$ Al-Qurțubī, Al-Jāmi’ li Aḥkām al-Qurān, 2: 284-288.
} 
Translation: "The example of those who spend their wealth in the way of Allah is like a seed [of grain] which grows seven spikes; in each spike is a hundred grains. And Allah multiplies [His reward] for whom He wills. And Allah is allEncompassing and Knowing,"93.

Al-Baqarah 2:261

In this verse Allah SWT describes the impact of giving for charity like a growing seed that multiplies from a tiny seed into seven spikes that each contains a hundred grains. Al-Marāgh ${ }^{-94}$ reported that a group of researcher conducted an experiment in 1942 to prove the multiplication of a sown seed of grain as stated in the Quran. As a result, they found that a spike produces 107 seeds. This proves the truth of this verse and the fact that an act of charitable giving triggers a spill over impact to the society estimating to 700 times. Meanwhile Ibn Kathīr ${ }^{95}$ elaborates on this verse from different angle. He suggests that this analogy refers to the reward promised by Allah SWT to those who spend for the sake of Allah that He will reward the deed in 10 to 700 folds. Wahbah al-Zuhayli ${ }^{-96}$ concludes that a charitable giving act impacts in multifold to both the doer and the society. The growing benefit is illustrated when a donor plays its economic role in giving charity to a receiver, the positive impact will be gained by the nation as it reduces the cost of management in many ways. The positive impact received by the nation is then manifested through better services to the society that includes the donor. The chain effect of the growing benefit is described in the following diagram in the Figure 2:

93 Abdul Malek Mujahid, Tafsir Ibn Katsir/ Abridged by a Group of Scholars Under the Supervision of Shaykh Safi Ur Rahman al-Mubarakpuri, 2:44.

94 Al-Marāghī, Tafsīr al-Marāghī, 1:268-271.

${ }^{95}$ Ibn Kathīr, Tafsìr al-Qurān al-Ażìm, 1/ 2:414-415.

96 Al-Zuhaylī, al-Tafsìr al-Munīr fì al-'Aqīdah wa al-Sharī'ah wa al-Manhaj, 2:.44-55. 


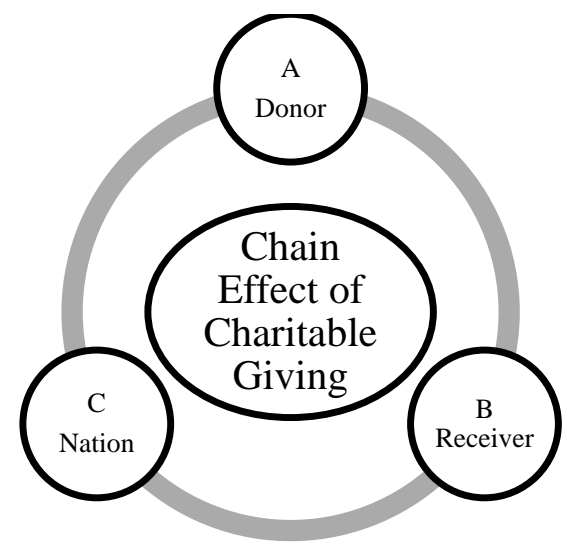

Figure 2: The Chain Effect of Charitable Giving

The impact of charitable giving is also discussed in verse 265 of the same surah:

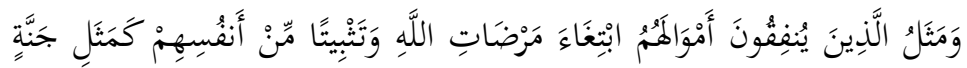

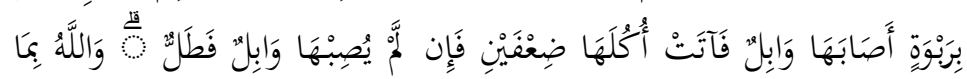

$$
\begin{aligned}
& \text { تَعْمَلُونَ بَصِيرُ }
\end{aligned}
$$

Translation: "And the example of those who spend their wealth seeking means to the approval of Allah and assuring [reward for] themselves is like a garden on high ground which is hit by a downpour - so it yields its fruits in double. And [even] if it is not hit by a downpour, then a drizzle [is sufficient]. And Allah, of what you do, is Seeing"97.

Al-Baqarah 2:265

Allah SWT symbolizes the deed by those who spend their wealth for the sake of God is like a garden on high ground that stays fertile on heavy rain and light rain. This shows that the nature of sincere giving deed is that its goodness grows and never goes barren. It also implies that Allah accepts and increases the deed and that none of them escapes His watch. ${ }^{98}$ Wahbah al-

\footnotetext{
97 Abdul Malek Mujahid, Tafsir Ibn Katsir/ Abridged by a Group of Scholars Under the Supervision of Shaykh Safi Ur Rahman al-Mubarakpuri, 2:50.

${ }^{98}$ Ibn Kathīr, Tafsīr al-Qurān al- 'Aż̄im, 1/ 2:417.
} 
Zuhayli ${ }^{99}$ further elaborates the meaning by explaining that sincere deed of giving produces good results that are abundant, continuous and sustainable. Al-Marāghī ${ }^{100}$ explains that Allah symbolizes the soul of generous being is like a fertile tree at the highest ground with plenty of water and sun which gives more during good times and gives whatever it can during hard times consistently.

The indication of growing effect of charity is also seen in the following verse as explained by Ibn Kathir ${ }^{101}$ that Allah forbids usury but increases the charity and makes it grow. Although the nature of riba or ususry is to substantiate the amount but eventually it will end in less which is in contrast to charity that has growing effect. Al-Qurtubi ${ }^{-102}$ opines that Allah erases the blessing of wealth for those who practice usury and Ibn Abbas defines that the destruction will come during the hereafter when all religious deeds are not accepted due to involvement in usury. While the word yurbi or grow for charity means the wealth is blessed in the world and the reward is multiplied in the hereafter. Wahbah alZuhayli clarifies the verse by stating that Allah reduces the wealth gained from usury and increases the wealth due to giving șadaqah ${ }^{103}$.

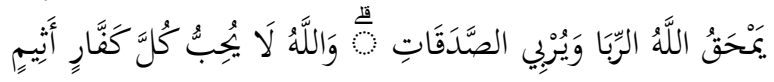

Translation: "Allah destroys interest and gives increase for charities. And Allah does not like every sinning disbeliever"104.

Al-Baqarah 2:276

The act of giving for charity is also portrayed as advancing loan to the God. The usage of the word loan literally means that the loan must be returned to the loaner. Not only Allah symbolizes the giving as a loan which temporarily taken from the loaner and must be repaid but also He promises a grand reward for doing so:

99 Al-Zuhaylī, al-Tafsìr al-Munīr fì al-'Aqīdah wa al-Sharī'ah wa al-Manhaj, 2:56-63.

${ }^{100}$ Al-Marāghī, Tafsīr al-Marāghī 1:272-273.

${ }^{101}$ Ibn Kathīr, Tafsīr al-Qurān al-'Azìm, 1/ 2:430-432.

102 Al-Qurțubī, al-Jāmi' li Aḥkām al-Qurān, 2: 298-317.

${ }^{103} \mathrm{Al}$-Zuhaylī, al-Tafsìr al-Munīr fì al-'Aqīdah wa al-Sharī'ah wa al-Manhaj 2:90-111.

${ }^{104}$ Abdul Malek Mujahid, Tafsir Ibn Katsir/ Abridged by a Group of Scholars Under the Supervision of Shaykh Safi Ur Rahman al-Mubarakpuri, 2:75. 


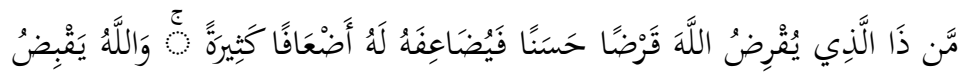

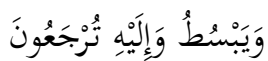

Translation:"Who is it that would loan Allah a goodly loan so He may multiply it for him many times over? And it is Allah who withholds and grants abundance, and to Him you will be returned ${ }^{105 " \text { ". }}$

Al-Baqarah 2:245

Wahbah al-Zuhayli ${ }^{106}$ elaborates that Allah SWT aims to eliminate two destructive attitudes of a human being that is coward and stingy by offering the greatest offer. The greatest offer which is al-Qardh or a loan lent to the God who is the most powerful and the controller of the provisions. The word al-Qardh is further explained by al-Qurțub $\overline{1}^{107}$ who states that Al-Qardh or loaning to Allah SWT is to spend money for Jihad that is for the sake of Allah. It is also put forward to describe that return is guaranteed by Allah SWT as any loans must be returned and that it is promised in multifold.

The warranty of repayment for charitable act by the God is also evident in the following verse of Surah al-Anfal:

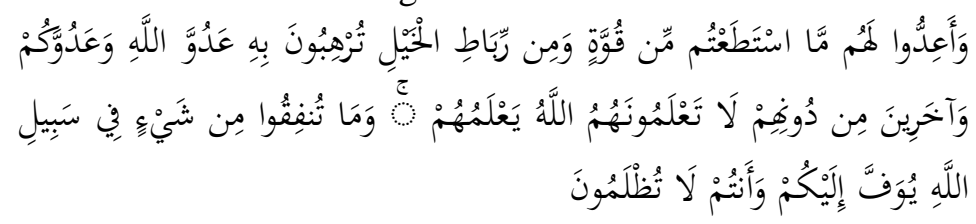

Translation:"And prepare against them whatever you are able of power and of steeds of war by which you may terrify the enemy of Allah and your enemy and others besides them whom you do not know [but] whom Allah knows. And whatever you spend in the cause of Allah will be fully repaid to you, and you will not be wronged." 108

Al-Anfāl 8:60

\footnotetext{
105 Abdul Malek Mujahid, Tafsir Ibn Katsir/ Abridged by a Group of Scholars Under the Supervision of Shaykh Safi Ur Rahman al-Mubarakpuri, 1:680.

106 Al-Zuhaylī, al-Tafsīr al-Munīr fì al-'Aqīdah wa al-Sharī'ah wa al-Manhaj, 2:781-790.

${ }^{107}$ Al- Qurțubī, al-Jāmi’ li Aḥkām al-Qurān, 2: 201-206.

${ }^{108}$ Abdul Malek Mujahid, "Tafsir Ibn Katsir/ Abridged by a Group of Scholars Under the Supervision of Shaykh Safi Ur Rahman al-Mubarakpuri, 4:343.
} 
Ibn Kathīr explains that the full repayment is guaranteed by Allah of whatever spent on jihad ${ }^{109}$. Al-Qurtubi discusses on the meaning of infaq in this verse which carries several meanings such as whatever given for charity and whatever spent on ownself and the horses for the sake of jihad. There is also a firm promise by the God that those who do so will be rewarded in the hereafter where a good deed is repaid from 10 to 700 folds and infinity. ${ }^{110} \mathrm{Al}$ Marāghī states that everything spent in the way of Allah will be repaid by Him and that the strength of the ummah can be achieved through charitable giving by channeling the charity to better equip the Muslim in facing the coming tribulations and this is the promise from the God that those who do so will not be oppressed and mistreated and will be completely replaced in the world and hereafter ${ }^{111}$.

Similarly, the term of loaning for charitable giving is also evident in Surah al-Hadid verse 18 which is promised to be returned, multiplied and given noble reward.

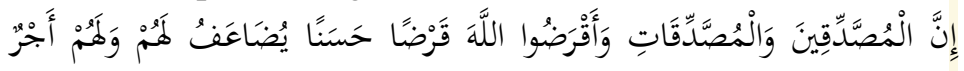

$$
\text { كَيقيمَ }
$$

Translation: "Indeed, the men who practice charity and the women who practice charity and [they who] have loaned Allah a goodly loan - it will be multiplied for them, and they will have a noble reward ${ }^{112}$.

Al-Hadīd 57:18

Ibn Kathīr ${ }^{113}$ and Al-Marāghī ${ }^{114}$ explain that this verse indicate that both men and women who spend sincerely to seek Allah's pleasure especially in helping the poor and the needy will be rewarded in ten to 700 fold. Al-Qurtubi ${ }^{115}$ and explicates that this verse refers to the voluntary charitable giving by both men and women that will be repaid in $10,70,700$ until infinity folds

${ }^{109}$ Ibn Kathīr, Tafsīr al-Qurān al- 'Az̄ìm, 3/4:55-57.

${ }^{110}$ Al- Qurțub̄̄, al-Jāmi’ li Ahkām al-Qurān, 4: 394-397.

${ }_{111}$ Al-Marāghī, Tafsīr al-Marāghī, 4:13-15.

112 Abdul Malek Mujahid, Tafsir Ibn Katsir/ Abridged by a Group of Scholars Under the Supervision of Shaykh Safi Ur Rahman al-Mubarakpuri, 9:485.

${ }^{113}$ Ibn Kathīr, Tafsīr al-Qurān al- 'Ażìm, 7/8:17-19.

${ }_{114}$ Al-Marāghī, Tafsir al-Maraghiy, 9:331.

${ }^{115}$ Al-Qurțub̄i, al-Jāmi‘ li Aḥkām al-Qurān, 9:209-210. 
and they ultimately will be rewarded with paradise. In short, these Quranic verses describe the nature of charity that expands and grows the capital and its repayment is guaranteed by the God Himself showing that any individuals or institutions that practice charity will never experience loss but will gain prosperity.

\section{Conclusion}

As a conclusion, the discussion on the verses of Quran and alHadith pertaining charity denotes that the definition of charitable giving in Islam is different from the common definition of charity which is aimed to help the needy for the love of mankind whereas the giving in Islam is meant to help the needy not only for the sake of mankind but it moves further to gain the love of Allah. There are many classifications of charitable giving which are broken down into two major categories namely the voluntary charitable giving and the mandatory charitable giving. These two major components are further classified into significant categories showing the expanded elaboration of both components especially the voluntary charitable giving component that includes the different mechanisms of voluntary charitable giving such as waqf, hibah, hadiyah and wasiah as well as the nonmaterial giving. Four important components of charitable giving which are the donor, the recipients, the gift and the intention are also discussed which indicate the dynamic and flexibility of voluntary charitable giving that is not restricted to any specific donor, amount and recipient. Finally the elaboration of its economic role based on the verses of Quran depicts the growing nature of charitable giving that benefit the donor, the recipient and the society as a whole.

\section{References}

'Alī Ibn Muhammad, Al-Jumu'ah. Mu'jam al-Muștalahāt alIqtisadiyyah wa al-Islāmiyyah. Riyadh: Maktabah al-'Ubaykat, 2000.

Al-Marāghī, Aḥmad Muștafā. Tafsir al-Marāghī. Beirut: Dār alFikr, 2001.

Al-Marbawi, Muhammad Idris Abdul Rauf. Kamus al-Marbawi. Egypt: Muștafā al-Bābī al-Halabī wa Awlādihi, 1929. 
Al-Nawāwī, Yaḥyā Ibn Sharaf. Al-Manhaj fì Sharh Șaḥịh Muslim Ibn Hajjaj al-Musamma Ikhtișāran Sharḥ Șaḥ̄ḥ Muslim. Beirut: Dār al-Khayr, 1999.

Al-Qurțub̄̄, Muḥammad bin Aḥmad al-Anșārī. Al-Jāmi` li Aḥkām al-Qurān. Cairo: Dār al-Hadīth, 2002.

Al-Sijistān̄̄, Abī Dawūd Sulaymān Ibn al-Ash'ath. Sunan Abi Dawūd. Beirut: Dār al-Fikr, 1999.

Al-Zuhaylī, Wahba.h Al-Fiqh al-Islāmī wa Adillatuhu. Damascus: Dār al-Fikr, 1989.

Al-Zuhaylī, Wahbah. Al-Tafsīr al-Munīr fi al-'Aqīdah wa alSharī'ah wa al-Manhaj. Damascus: Dār al-Fikr, 2003.

Bensaid, Benaouda and Grine, Fadila. "Ethico-Spiritual Dimensions of Charity: An Islamic Perspective," Middle-East Journal of Scientific Research 13 (2013): 65-77, doi:10.5829/idosi.mejsr.2013.13.e.13015.

Chambers, Federal. Advanced English Dictionary, English-Bahasa Malaysia Edition. Selangor: Chambers Harrap Publishers ltd, 2000.

Ibn Kathīr, Ismā‘īl bin Kathīr al-Damsyīqī. Tafsīr al-Qurān al'Azìm. Egypt: Maktabah al-Tawfiqia, 2000.

Ibn Manẓūr, Muhammad bin Mukarram bin 'Alī. Lisān al- 'Arab. Kaherah: Dār al-Ma‘ārif, 1999.

Malek Mujahid, Abdul. "Tafsir Ibn Katsir/ Abridged by a Group of Scholars under the Supervision of Shaykh Safi Ur Rahman al-Mubarakpuri". Riyadh: Darussalam Publishers \& Distributors, 2000.

Penrice, John. A Dictionary and Glossary of the Quran. Kuala Lumpur: The Other Press, 2006.

Qadhi, Yaser. English Translation of Sunan Abu Dawud. Riyadh: Darussalam, 2008.

Siddiqi, Abdul Hamid. Sahih Muslim; Arabic-English. India: Adam Publishers \& Distributors, 1999. 